\title{
Correlation of multiple deformation events in an area: Example from schistose rocks of Lesser Himalayas, NW Pakistan
}

\author{
Mustafa $\mathrm{YAR}^{1,2} \odot$ \\ ${ }^{1}$ Department of Geology, FATA University, Akhurwal, Darra Adam Khel, District Kohat, Pakistan. \\ ${ }^{2}$ National Centre of Excellence in Geology, University of Peshawar, Peshawar, Khyber Pakhtunkhwa, Pakistan. \\ e-mail: mustafa.afridi@yahoo.com
}

MS received 19 January 2018; revised 14 July 2018; accepted 14 September 2018; published online 11 April 2019

Integrated micro-, meso- and macro-structural investigations were carried out in the multiply deformed rocks of the Mula Gori area, northeastern Khyber Agency, Lesser Himalayas. These investigations revealed an intricate history of deformation events that have not been formerly recognised. These structural examinations show four successive deformations. These events were identified in the field as well as in oriented vertical thin sections. The first deformation event $\mathrm{D}_{1}$ is preserved in the form of inclusion trails in garnet porphyroblasts of foliation intersection axis 1 (FIA 1) and the fold axis of the macroscopic fold indicates NW-SE orogeny-oblique shortening. The $\mathrm{D}_{2}$ event produced $\mathrm{N}-\mathrm{S}$ trending foliations, fold axes and mineral lineations indicating $\mathrm{E}-\mathrm{W}$ shortening. The $\mathrm{D}_{3}$ is preserved as FIA 2 in garnet porphyroblast and $\mathrm{E}-\mathrm{W}$ trending foliations, mineral lineations and fold axes in the field representing $\mathrm{N}-\mathrm{S}$ shortening. The $\mathrm{D}_{4}$ created NNW-SSE fabrics, which post-dates the main mantle thrust and the main boundary thrust, and likely resulted from the ENE-WSW bulk shortening related to development of the Hazara-Kashmir syntaxis.

Keywords. Porphyroblast; microstructures; mesoscopic structures; Mula Gori area; Lesser Himalayas.

\section{Introduction}

Eurasian and Indian plates are directly in contact with India and Nepal (Mukherjee et al. 2013, 2015; Mukherjee 2013, 2015), but are separated from one another by the sequence of rocks of the Kohistan arc in Pakistan (Gansser 1964). Northern Pakistan encompasses three major tectonostratigraphic components (DiPietro and Pogue 2004). These are (i) the Kohistan island arc, (ii) the main mantle thrust (MMT, mélange group) and (iii) the Indian plate rock sequence. These blocks are separated by the MMT and the main boundary thrust (MBT) (Tahirkheli 1979; Pogue et al. 1999).
The MMT separates the rocks of the Indian plate from Kohistan island arc (Tahirkheli 1979; Treloar et al. 1992). The tectonic block present between the MMT and the MBT is termed as the Himalayan foothills that accounts for the increase in the grade of metamorphism and deformation towards the north (Pogue et al. 1999). This tectonic unit is divided by the east trending Panjal-Khairabad Fault by an internal zone in the north and an external zone to the south (Coward et al. 1988). DiPietro et al. (2008) designate the internal zone as the western hinterland zone. The present study area (Mula Gori $\sim 36 \mathrm{~km}^{2}$ ) lies in the NE Khyber Agency and consists of deformed metasedimentary 


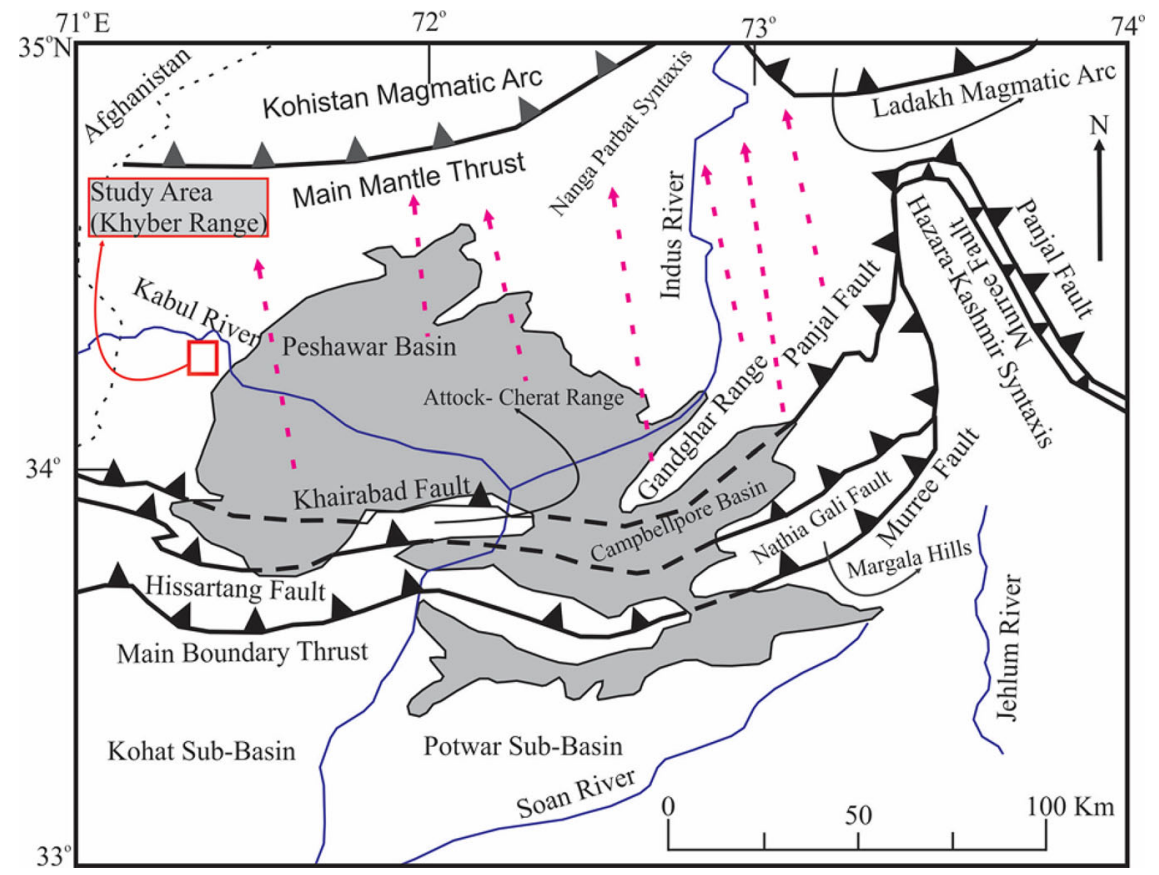

Figure 1. Regional tectonic map of Pakistan demonstrating the tectonic terrain separated by the MMT and MBT. The box (square) shows the location of the study area at the left of the map while the dashed arrows represent the increase in the grade of metamorphism and deformation from the south towards the north (after Kazmi and Rana 1982; Ali et al. 2016).

rocks (Silurian-Devonian Lowara Mena Formation and Warsak Metamorphic Complex; figure 1; Kazmi and Rana 1982; Khan et al. 1989). The study area comprises metasediments of greenschist and lower amphibolite facies (Ahmad et al. 1969; Ali et al. 2016). The tectonic and structural relationship of the western part of the western hinterland zone is poorly understood because of the cover of younger sediments of the Peshawar basin on Palaeozoic rocks of the Mula Gori area (Burbank 1983). The type of current tectonic scenario in the area has been established on regional geological traverses and random petrography (cf. Ahmad et al. 1969; Shah et al. 1980; Khan et al. 1989). This research uses detailed mesoscopic structures at an outcrop scale supplemented with microscopic structures preserved in porphyroblasts and matrix from a part of the NE Khyber Agency to establish the interrelationship between structures in the western part of the western hinterland zone, Lesser Himalayas, Pakistan.

\section{Sample description}

For detailed petrographic studies, 50 oriented samples were collected from metamorphosed pelitic rocks exposed in the study area (figure 2). A total of 385 oriented vertical thin sections were prepared with different strikes from these oriented samples for petrographic and microstructural interpretations. Mineral assemblages in the studied rock samples consist of quartz, graphite, ilmenite, chlorite, chloritoid, biotite, muscovite, garnet, staurolite and pyrite. Microstructural data were mainly collected from garnet porphyroblasts due to nicely preserved sigmoidal inclusion trails and matrix foliations.

\subsection{Mineral assemblages}

\subsubsection{Garnet}

Garnets, present mainly in the form of porphyroblasts, are idioblast, hypidioblast and xenoblast and range in size from 0.5 to $2.5 \mathrm{~mm}$. These garnet porphyroblasts contain sigmoidal inclusions of quartz, muscovite, ilmenite and biotite, which are either continuous or discontinuous with respect to the matrix foliation (figure 3). These sigmoidal inclusion trails preserved in garnet porphyroblasts are much finer grained than similar grains in the matrix.

\subsubsection{Staurolite}

The staurolite porphyroblasts exist only in three samples. The matrix foliation strongly wraps the porphyroblast and contains poorly preserved inclusion trails of quartz (figure 4). 


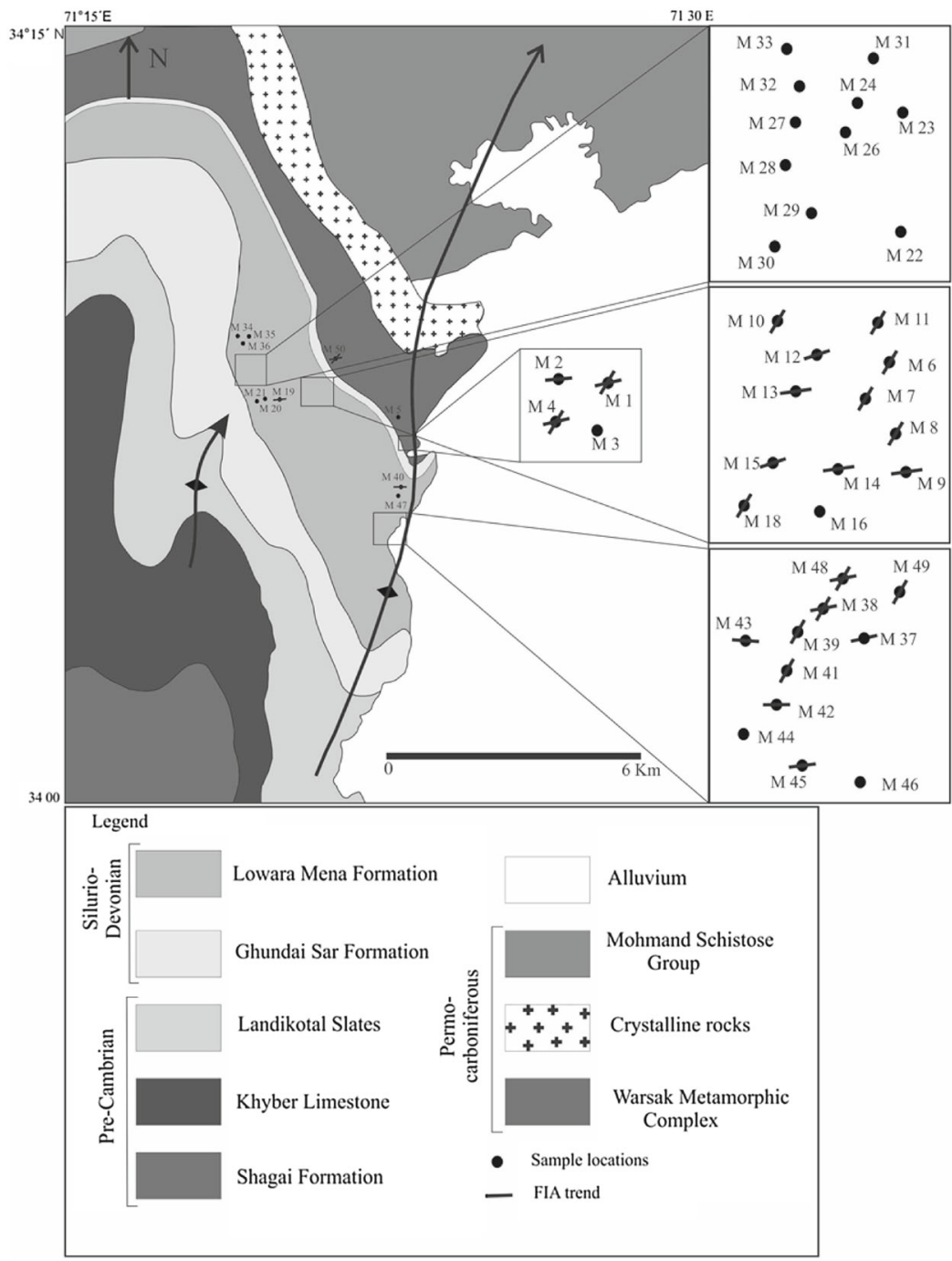

Figure 2. Detailed geological map of the Mula Gori area, northeastern Khyber Agency showing major stratigraphic units and sample locations (after Khan et al. 1989).

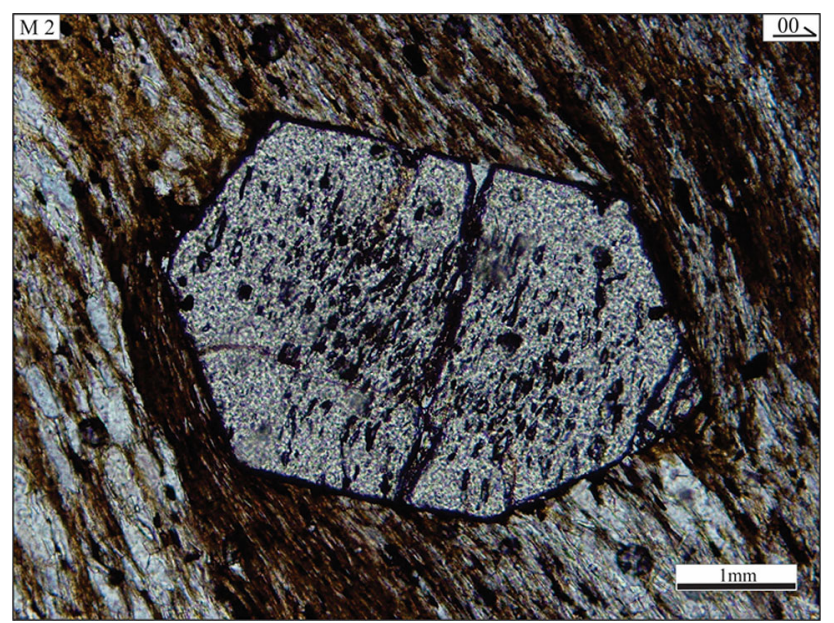

Figure 3. Photomicrograph of a vertical thin section showing continuous inclusion trails in an idiomorphic garnet porphyroblast that are passing continuously into the matrix. Single barbed arrow shows strike and way up.

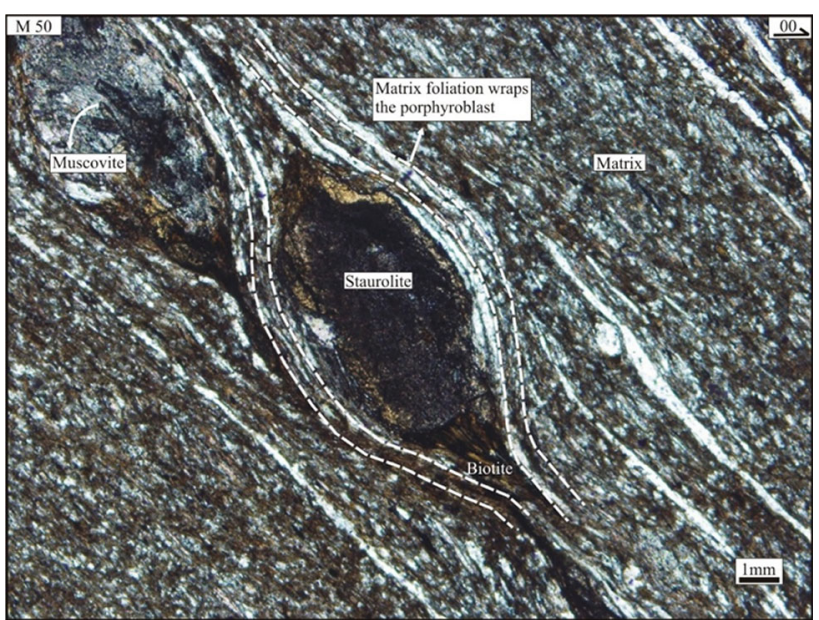

Figure 4. Photomicrograph showing elongated staurolite porphyroblast in the zone of a strong non-coaxially deformed matrix. Single barbed arrow shows strike and way up. 


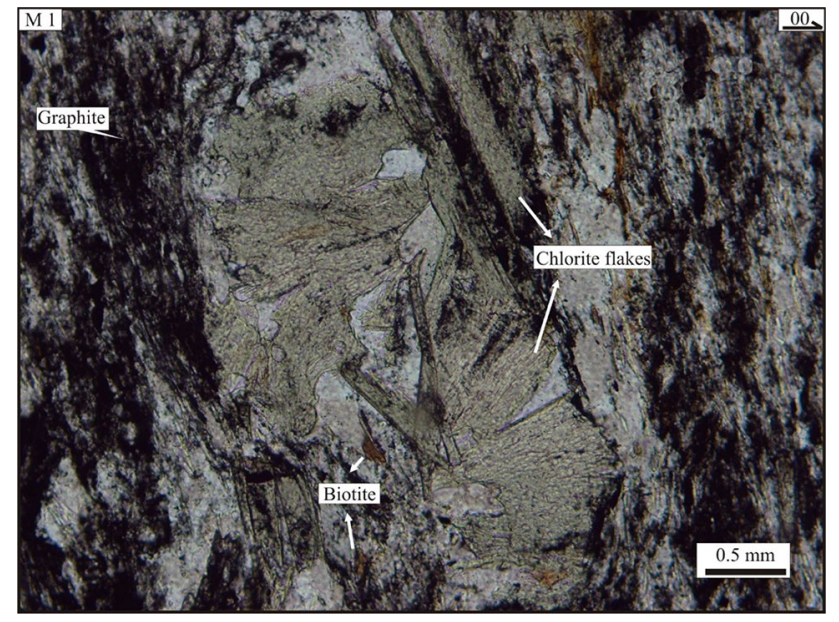

Figure 5. Photomicrograph showing differentiated crenulated cleavage with chlorite flakes in microlithon in graphitic schist. Single barbed arrow shows strike and way up.

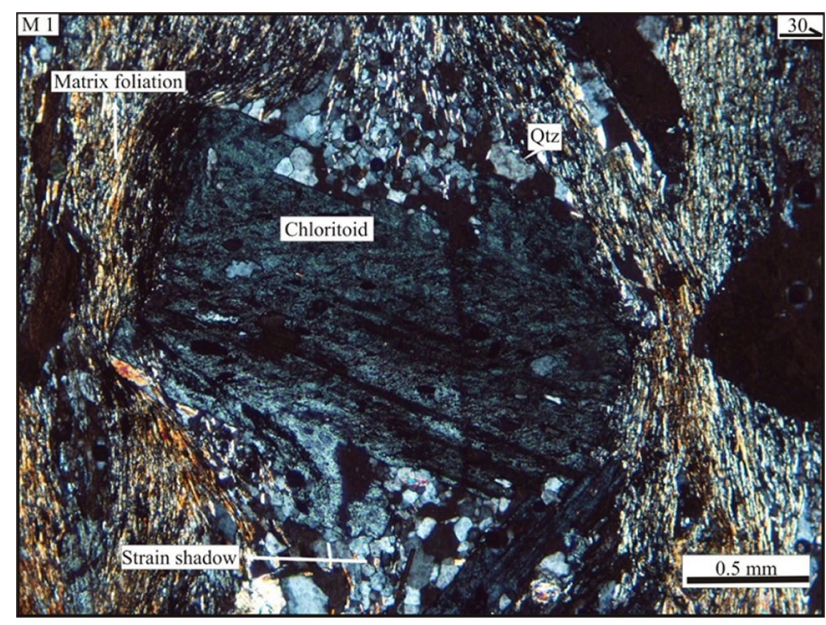

Figure 6. Photomicrograph showing inclusion trails of chloritoid porphyroblast that are truncated by later deformation in the matrix. Single barbed arrow shows strike and way up.

\subsubsection{Chlorite, biotite and muscovite}

Chlorite is primarily found in differentiated cleavages with a few large flakes in crenulation hinges (figure 5). Biotite mostly defines the main matrix foliation. Staurolite and garnet porphyroblasts are largely enclosed by biotite in the differentiated crenulation cleavages. Muscovite is generally less and finer grained than biotite in the studied thin sections.

\subsubsection{Chloritoid}

Chloritoid exists in two samples in the form of porphyroblast (figure 6). It occurs in close association with chlorite. The development of a differentiated crenulation cleavage in the matrix truncates/ cuts poorly preserved inclusion trails within the chloritoid porphyroblast.

\section{Foliation intersection axes (FIA)}

The FIA technique was first introduced by Hayward (1990) and refined by Bell and Hickey (1998) and Bell et al. (1995, 2004). This technique involves observing the shift in the asymmetries of curved inclusion trails, preserved in porphyroblasts, in a series of differently oriented vertical thin sections. In the beginning, from every sample six oriented vertical thin sections were cut at every $30^{\circ}$ interval from true north (figure 7). Extra thin sections were cut at $10^{\circ}$ interval to limit the FIA range within $\pm 5^{\circ}$ from the same sample (see for detail Bell and Hickey 1998; Bell et al. 2004). The FIA trend is regarded as the mid between two oriented vertical thin sections across which the change in the asymmetries of inclusion trails occurs.

The relative timing between different FIA sets is decided on the following rules:

(1) Numerous FIAs investigation, i.e., change in the trends of FIAs from core to rim (Bell and Hickey 1998; Bell et al. 2004; Bell and Welch 2002).

(2) Continuity and truncation of inclusion trails in porphyroblast with the matrix foliation (cf. Adshead-Bell and Bell 1999; Ali et al. 2016).

(3) Trend of inclusion trails whether it is at high angle or parallel with respect to the matrix foliation (Sayab 2005, 2008; Sanislav 2010; Sharib and Bell 2011).

\subsection{FIA sets}

Total 31 FIAs were measured from garnet porphyroblasts present in 26 oriented samples (table 1). The remaining oriented samples do not have porphyroblasts. The schistose rocks of the study area contain two FIA sets with NNE-SSW and ENE-WSW orientations.

\subsubsection{FIA set 1}

This trends NNE-SSW and exists in the core of garnet porphyroblasts and in garnets where the inclusion trails are sharply or partially truncated by the matrix (figure 8). This FIA set was not detected in garnets containing inclusion trails 

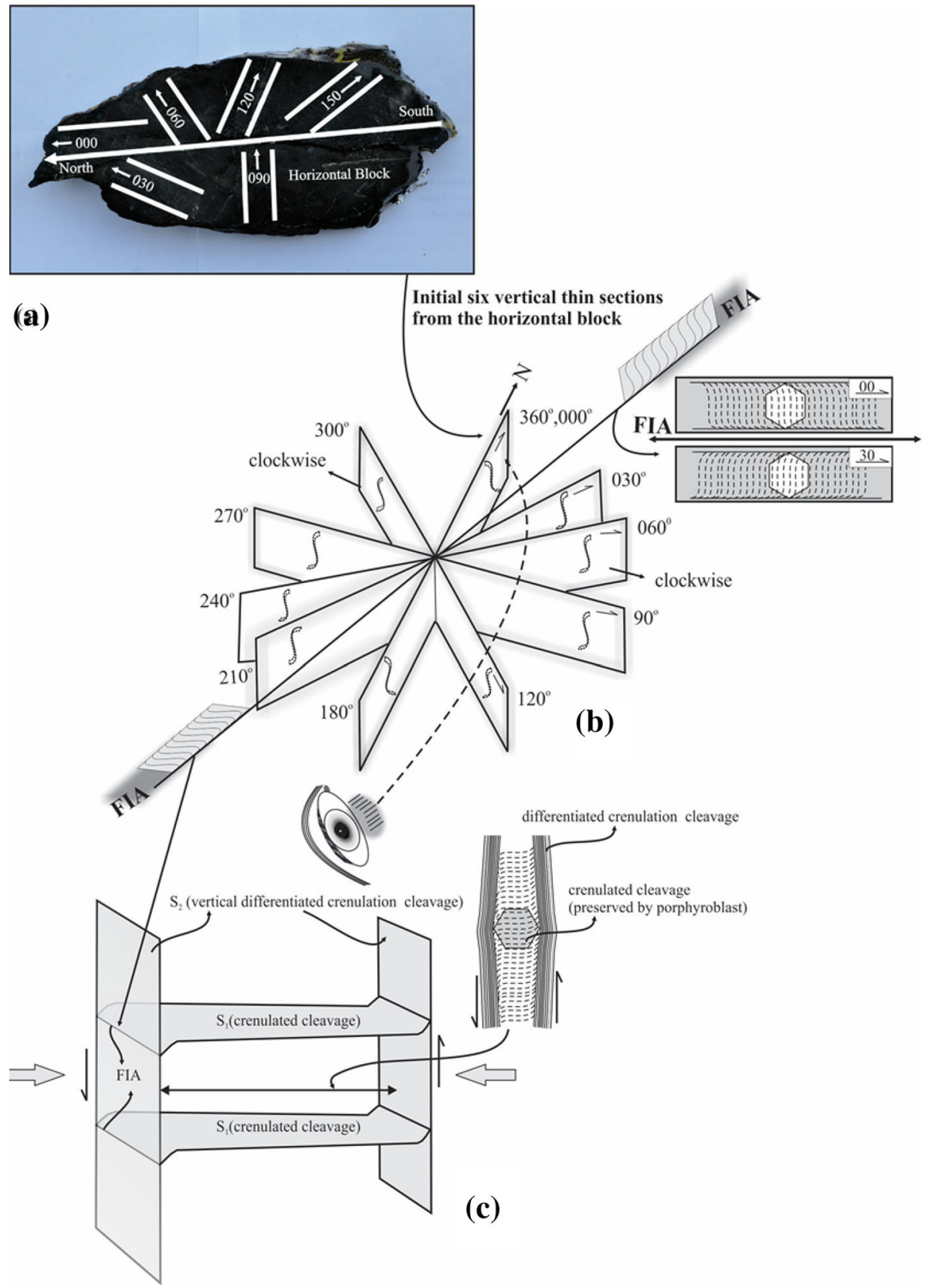

Figure 7. Sketches illustrating the FIA measurement technique in a series of six vertically oriented thin sections cut from a horizontally oriented block. Note the thin sections are viewed in a single direction across the compass (modified after Ali 2010).

continuous with the matrix foliation. FIA 1 trends at an average of $035-045^{\circ}$.

\subsubsection{FIA set 2}

This trends ENE-WSW and occurs in the rim of garnet porphyroblasts containing nicely developed core and from garnets with well-developed inclusion trails that are passing continuously into the matrix foliation. FIA 2 orientation varies from 070 to $085^{\circ}$ (figure 9 ). The orientation of these FIAs is shown in a rose diagram (figure 10; cf. Ali et al. 2016).

\section{Structural field/outcrop data}

Foliation overprinting relationships in the Mula Gori area show four successive deformation events named $\mathrm{D}_{1}, \mathrm{D}_{2}, \mathrm{D}_{3}$ and $\mathrm{D}_{4}$. Each deformation event in terms of foliation i.e., $\mathrm{S}_{1}, \mathrm{~S}_{2}, \mathrm{~S}_{3}$ and $\mathrm{S}_{4}$ is discussed below. Field data are given in table 2 . 
Table 1. Sample locations and foliation intersection axes.

\begin{tabular}{|c|c|c|c|c|}
\hline $\begin{array}{l}\text { Sl. } \\
\text { no. }\end{array}$ & Easting & Northing & FIA 1 & FIA 2 \\
\hline M1 & $712255.4 \mathrm{E}$ & $340706.3 \mathrm{~N}$ & 40 & 80 \\
\hline M2 & $712254.3 \mathrm{E}$ & $340706.4 \mathrm{~N}$ & & 90 \\
\hline M4 & $712254.0 \mathrm{E}$ & $340706.0 \mathrm{~N}$ & 35 & 70 \\
\hline M6 & $712057.9 \mathrm{E}$ & $340809.0 \mathrm{~N}$ & 40 & \\
\hline M7 & $712058.6 \mathrm{E}$ & $340806.9 \mathrm{~N}$ & 35 & \\
\hline M8 & $712104.8 \mathrm{E}$ & $340804.9 \mathrm{~N}$ & 40 & \\
\hline M9 & $712106.1 \mathrm{E}$ & $340759.9 \mathrm{~N}$ & & 90 \\
\hline M10 & $712054.3 \mathrm{E}$ & $340813.8 \mathrm{~N}$ & 55 & \\
\hline M11 & $712053.1 \mathrm{E}$ & $340813.7 \mathrm{~N}$ & 35 & \\
\hline M12 & $712054.5 \mathrm{E}$ & $340808.6 \mathrm{~N}$ & & 70 \\
\hline M13 & $712052.3 \mathrm{E}$ & $34080.80 \mathrm{~N}$ & & 85 \\
\hline M14 & $712051.2 \mathrm{E}$ & $34080.08 \mathrm{~N}$ & & 70 \\
\hline M15 & $712045.4 \mathrm{E}$ & $340800.5 \mathrm{~N}$ & & 70 \\
\hline M18 & $712038.8 \mathrm{E}$ & $340754.5 \mathrm{~N}$ & 40 & \\
\hline M19 & $712012.7 \mathrm{E}$ & $340751.5 \mathrm{~N}$ & & 70 \\
\hline M37 & $712224.5 \mathrm{E}$ & $340519.9 \mathrm{~N}$ & & 75 \\
\hline M38 & $712222.1 \mathrm{E}$ & $340522.7 \mathrm{~N}$ & 35 & 75 \\
\hline M39 & $712220.5 \mathrm{E}$ & $340522.4 \mathrm{~N}$ & 35 & \\
\hline M40 & $7122.328 \mathrm{E}$ & $3405.371 \mathrm{~N}$ & & 85 \\
\hline M41 & $712217.7 \mathrm{E}$ & $340521.5 \mathrm{~N}$ & 40 & \\
\hline M42 & $712215.6 \mathrm{E}$ & $340520.7 \mathrm{~N}$ & & 90 \\
\hline M43 & $712211.6 \mathrm{E}$ & $340519.9 \mathrm{~N}$ & & 95 \\
\hline M45 & $712213.5 \mathrm{E}$ & $340459.1 \mathrm{~N}$ & & 70 \\
\hline M48 & $712233 \mathrm{E}$ & $340527.6 \mathrm{~N}$ & 35 & 70 \\
\hline M49 & $712245.4 \mathrm{E}$ & $340525.9 \mathrm{~N}$ & 35 & \\
\hline M50 & $712123.6 \mathrm{E}$ & $340820.8 \mathrm{~N}$ & 35 & 75 \\
\hline
\end{tabular}

\section{1 $D_{1}$ deformation $/ S_{1}$ fabric}

The recognition of an earliest $\mathrm{S}_{1}$ is often very confusing to decode in a tectonic terrain in terms of its original orientation because of the obliteration of $\mathrm{S}_{1}$ due to subsequent deformation events (Bell 1986). The evidence for $S_{1}$ cleavage only exists in thin sections where early formed porphyroblasts (e.g., garnet) contain oriented inclusion trails of quartz. $\mathrm{S}_{1}$ trending NNE-SSW is well preserved in the form of inclusion trails and predate all the deformation events in the study area hence regarded as the product of $D_{1}$.

\section{$4.2 D_{2}$ deformation $/ S_{2}$ fabric}

The $\mathrm{D}_{2}$ deformation event produced N-S striking upright tight folds at the outcrop associated with $\mathrm{N}-\mathrm{S}$ oriented $\mathrm{S}_{2}$ axial plane foliation. It is moderately to steeply dipping. $\mathrm{S}_{2}$ is generally parallel to bedding $\left(\mathrm{S}_{\mathrm{o}}\right)$ (figure $11 \mathrm{~A}$ and $\mathrm{B}$ ). $\mathrm{S}_{2}$ is locally developed and observed at a few places.

Lithology controls the orientation of cleavages in rocks (Huston 1990). Cleavages are usually parallel to bedding in less competent rocks but may tend to refract up to $60^{\circ}$ as they enter into more competent lithology. In the interbedded sequence of pelites and psammites, most of the strain associated with folding is absorbed/stored in the pelitic rocks (cf. Huston 1990). In the study area, $D_{2}$ associated cleavages are parallel to bedding in the pelitic unit (figure 11A and B) but as they enter the marbleised limestone unit they become steeply dipping in the form of axial planar foliation of tight folds in the area (figure 11C).

\section{$4.3 D_{3}$ deformation $/ S_{3}$ fabric}

The $\mathrm{S}_{3}$ fabric is well developed and sub-vertical in the region (figure $12 \mathrm{~A}$ and $\mathrm{B}$ ). $\mathrm{S}_{3}$ are best seen in the southern part of the Lowara Mena Formation. The $S_{3}$ foliations are orthogonal to the $S_{2}$ foliations in the pelitic unit and intersect $\mathrm{S}_{2}$ in the region (figure 12C). The intersection lineation of $\mathrm{S}_{3}$ and $\mathrm{S}_{2}$ trends ENE-WSW and is parallel to $\mathrm{D}_{3^{-}}$ related fold axes (figure $12 \mathrm{D}$ ). $\mathrm{D}_{3}$-related folds are upright close fold, slightly overturned and show southward vergence. Similarly, the mineral stretching lineation associated with $\mathrm{D}_{3}$ trends ENE-WSW.

\section{$4.4 \mathrm{D}_{4}$ deformation and $S_{4}$ fabric}

The $\mathrm{D}_{4}$ produced gently dipping $\mathrm{S}_{4}$ foliation which crenulates $S_{2}$ and $S_{3}$ in the region (figure 13). Mesoscopic folds associated with $\mathrm{D}_{4}$ exist across the Mula Gori region and are equally developed in the metapelitic, marbleised and metapsammitic rock units. The general trend of the axial plane foliation related with $\mathrm{D}_{4}$ is $340^{\circ}$ and dips gently towards $\mathrm{NE}$ at $\sim 45^{\circ}$.

Distinct cleavages observed mesoscopically in the field are $\mathrm{S}_{2}, \mathrm{~S}_{3}$ and $\mathrm{S}_{4}$, which developed during $\mathrm{D}_{2}$, $\mathrm{D}_{3}$ and $\mathrm{D}_{4}$ deformation events and their orientations are plotted in a rose diagram (figure 14). $\mathrm{S}_{3}$ and $\mathrm{S}_{4}$ are the most dominant and well preserved foliations of the area.

\section{Correlation of meso- and micro-scale structures}

Indications of numerous deformations were noticed both in meso- and micro-scale. Structures/foliations associated with successive deformation events in the porphyroblast and matrix were correlated from thin sections to outcrop scale in 

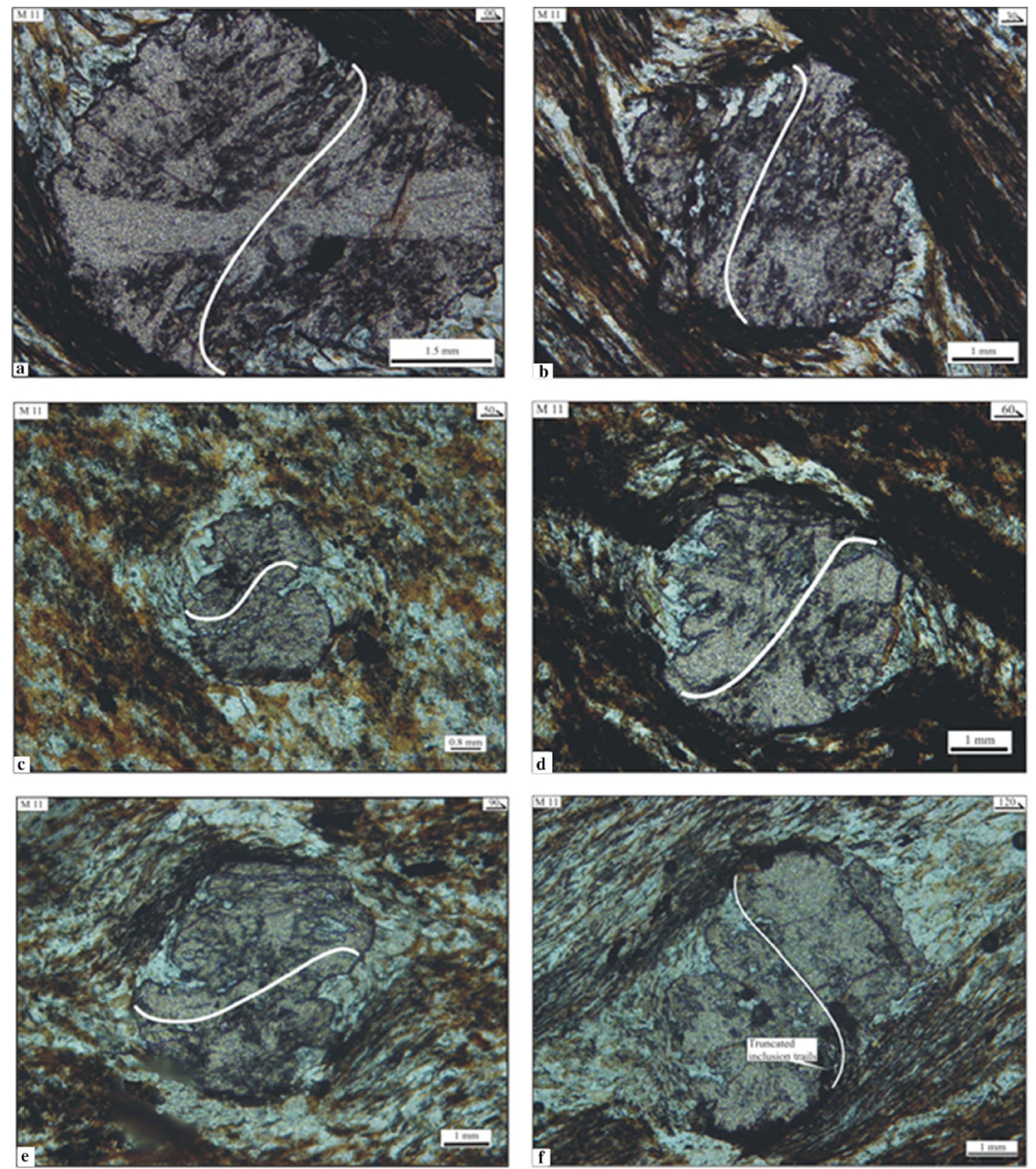

Figure 8. Inclusion trails in differently vertical sections of sample M11 showing FIA at $040^{\circ}$. Photomicrograph (f) showing truncated inclusion trails, which is approximately perpendicular to FIA.

terms of orientation, overprinting and cross-cutting relationships.

\section{$5.1 S_{1}$ meso- and micro-structures}

$\mathrm{S}_{1}$ is not preserved at the outcrop as it is primarily preserved in the form of sigmoidal inclusion trails in garnet porphyroblast. This cleavage has been obliterated/demolished by $\mathrm{D}_{2}$, $\mathrm{D}_{3}$ and $\mathrm{D}_{4}$ deformations within the matrix foliation apart from that preserved in the garnet porphyroblasts. $\mathrm{S}_{1}$ is preserved in the microlithon as the Q-domain (figure 15). The inclusion trails are mostly defined by oriented fine-grained quartz. $\mathrm{S}_{1}$ trends NNE-SSW, similar to the main macroscopic scale fold.

\section{$5.2 S_{2}$ meso- and micro-structures}

$\mathrm{S}_{2}$ is moderately to steeply dipping and trends $\sim \mathrm{N}$ (figure 11), parallel to bedding $\left(\mathrm{S}_{\mathrm{o}}\right)$ as noted at the outcrop. Correspondingly, in the studied vertical thin sections, $\mathrm{S}_{2}$ appears to be steeply dipping, oriented $\sim \mathrm{N}$ and preserved as cleavage or M-domain (figure 16A). The $\mathrm{S}_{2}$ cleavage in the metapelitic unit is mainly defined by biotite and graphite in the matrix. Mica concentrated in the form of cleavages around competent porphyroblasts leading to the 

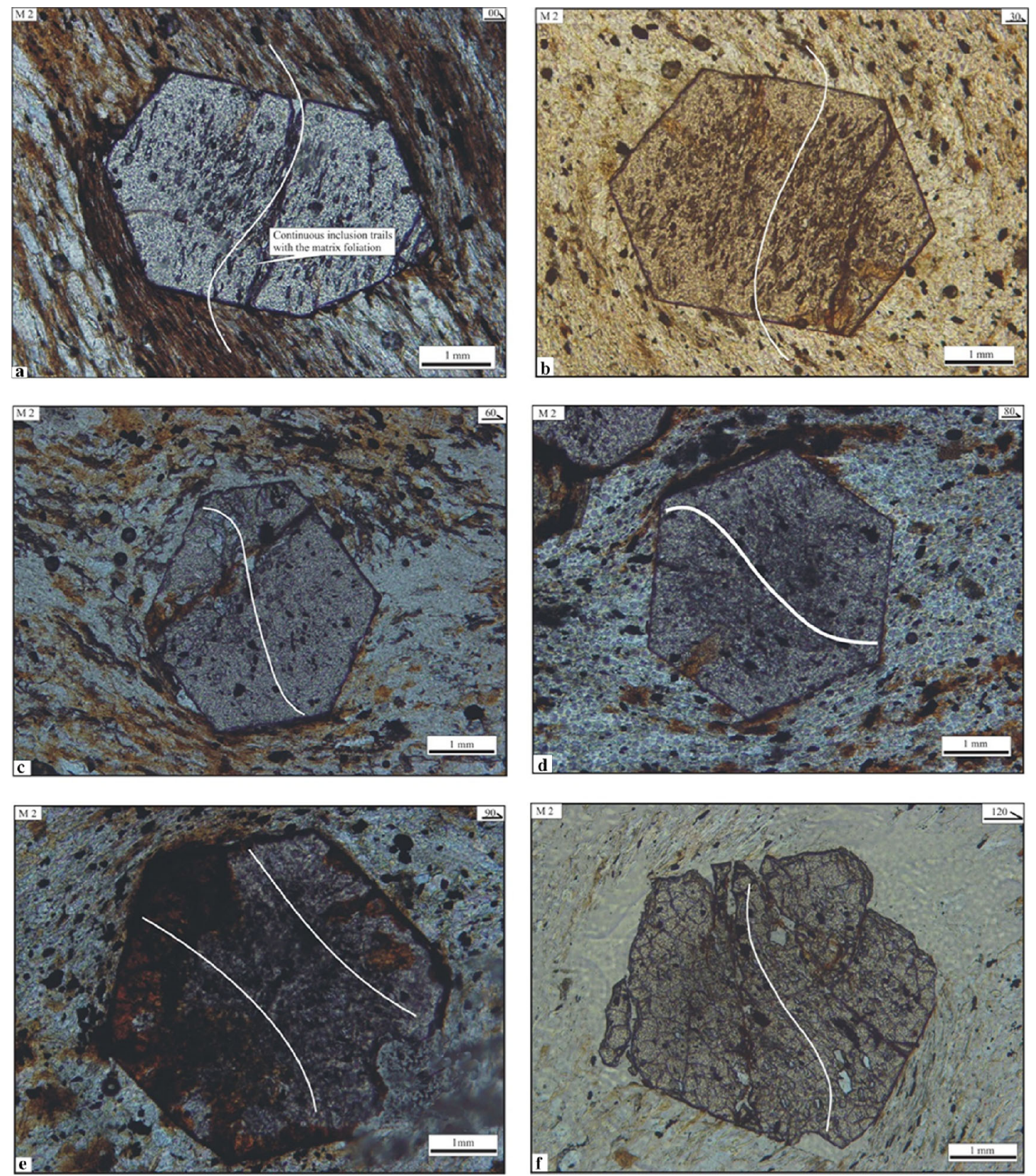

Figure 9. Inclusion trails in differently vertical sections of the sample M2 showing FIA at $090^{\circ}$. Photomicrograph (a) showing continuous inclusion trails, which is perpendicular to FIA.

development of symmetric strain shadows within the matrix (figure 16A). The symmetric strain shadows (cf. Mukherjee 2017) around porphyroblasts comprise quartz and mica.

\section{$5.3 S_{3}$ meso- and micro-structures}

At the outcrop scale, $\mathrm{S}_{3}$ is steeply dipping, ENEWSW trending and intersecting $\mathrm{S}_{2}$ at high angle $\left(70-80^{\circ}\right)$. In the oriented vertical thin sections $\mathrm{S}_{3}$ is steeply dipping, $070-090^{\circ}$ trending similar to that of field orientation (figure 17). $\mathrm{S}_{3}$ is preserved both as Q-domain in garnet porphyroblast and as M-domain in the matrix.

\section{$5.4 S_{4}$ meso- and micro-structures}

The $\mathrm{S}_{4}$ occurs as axial planar foliation at the outcrop and trends $330-340^{\circ}$. It dips moderately towards NE. Consequently, $\mathrm{S}_{4}$ is observed as axial planar foliation too in the oriented thin section and moderately dipping towards $070^{\circ}$. $\mathrm{S}_{4}$ is mainly preserved in the matrix (figure 18). 


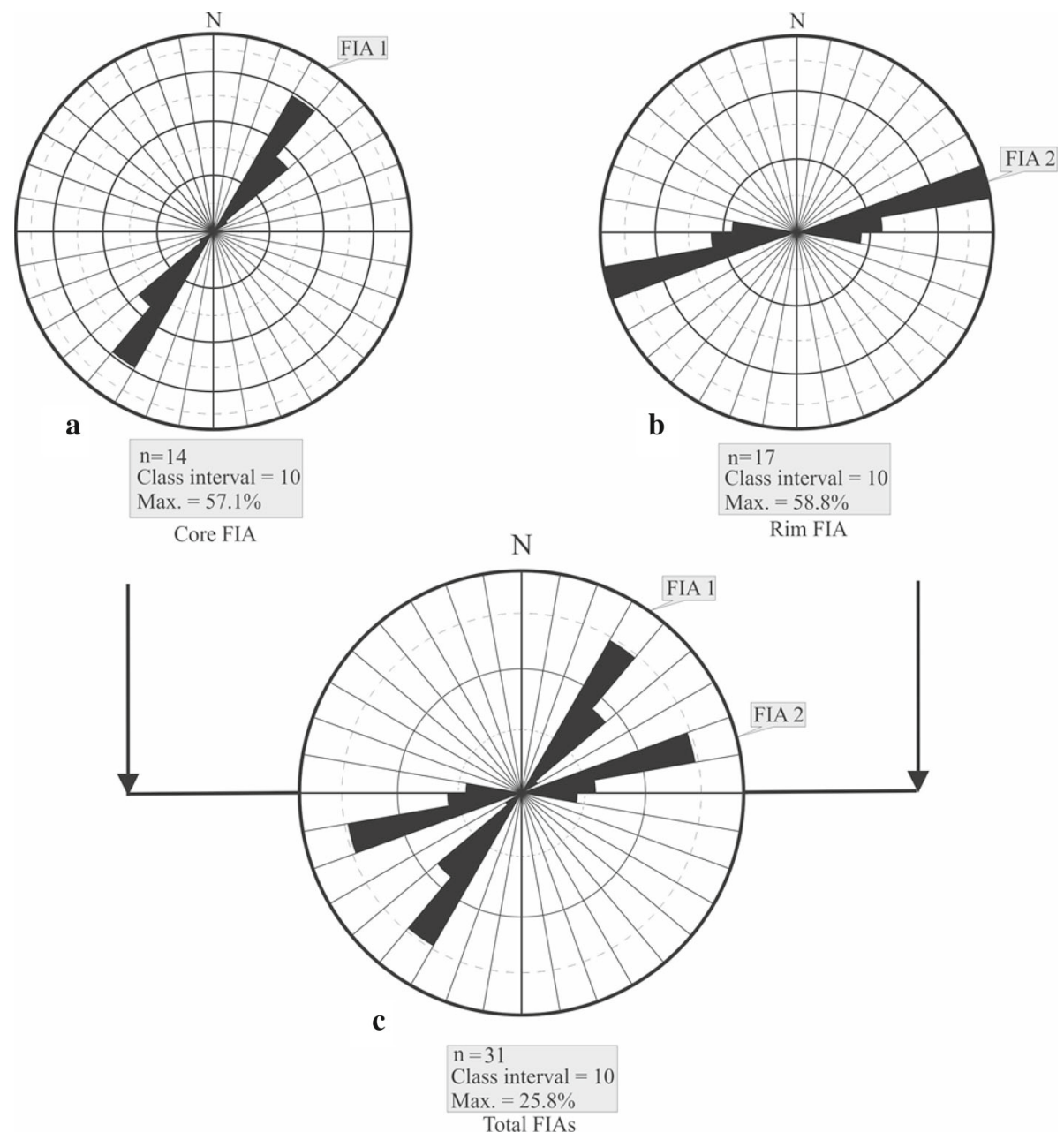

Figure 10. Equal area rose diagrams showing FIA sets 1 and 2 trends preserved within garnet porphyroblasts of at least two different generations in the Mula Gori area (after Ali et al. 2016).

\section{Discussions}

The NNE-SSW oriented FIA set 1 shows NWSE horizontal bulk shortening. The $\mathrm{D}_{2}$ designed $\mathrm{N}-\mathrm{S}$ oriented foliations, mineral lineations and fold axes and indicates $\mathrm{E}-\mathrm{W}$ shortening (see figure 11). ENE-WSW oriented foliations at outcrop and FIA 2 is the product of a $\mathrm{D}_{3}$ event. FIA set 2 is conserved in the rim of porphyroblasts containing FIA 1 in the core and in the porphyroblast where the sigmoidal inclusion trails are continuous with the matrix foliation, boudin lineation axes, intersection lineation $\left(\mathrm{L}_{3}^{2}\right)$ and mineral lineations $\left(\mathrm{L}_{3}^{3}\right)$ indicating $\mathrm{N}-\mathrm{S}$ shortening. Folds related to the $\mathrm{D}_{3}$ deformation event show southward vergence (see figure 12). The transposition of the gently dipping NNW-SSE oriented $\mathrm{D}_{4}$ deformation fabrics, boudin lineation axes, $\mathrm{L}_{4}^{4}$ mineral lineations and axial planar foliation shows a NE-SW horizontal bulk shortening within the study area. The NNE-SSW trending regional fold (Khan et al. 1989; Ali et al. 2016) is parallel to FIA 1 in the southwestern hinterland and pre-date all younger deformation events in the region. Formerly, regional-scale folds were decided on the basis of asymmetries of mesoscopic scale folds across the fold hinges and axial plane foliations. The transposition of foliations during the younger deformation events post-dates regional fold and can lead to incorrect information regarding the origin of a macroscopic scale fold in an area (cf. Bell et al. 2003). Bell et al. (2003) and Ham and Bell (2004) stated that once the large macroscopic folds initiate, they may tighten/shorten further during subsequent periods of shortening events but the main fold axis orientation remains the same as in the case of the Type-0 folding (see figure 19). The Kunar Fault which is the extension of main Karakorum thrust (MKT) predates all the deformation events in northern 
Table 2. Showing trends of meso-scale structures at the outcrop.

\begin{tabular}{|c|c|c|c|}
\hline $\begin{array}{l}\text { Sl. } \\
\text { no. }\end{array}$ & $\begin{array}{l}\mathrm{S}_{2} \text { foliation, } \\
\mathrm{L}_{2}^{2} \text { lineation }\end{array}$ & $\begin{array}{l}\mathrm{S}_{3} \text { (foliation), } \\
\mathrm{L}_{3}^{3} \text { (lineation) }\end{array}$ & $\begin{array}{l}\mathrm{S}_{4} \text { (foliation) } \\
\mathrm{L}_{4}^{4} \text { (lineation) }\end{array}$ \\
\hline 1 & 360 & 260 & 340 \\
\hline 2 & 355 & 265 & 330 \\
\hline 3 & 10 & 90 & 340 \\
\hline 4 & 180 & 270 & 340 \\
\hline 5 & & 100 & 320 \\
\hline 6 & & 100 & 320 \\
\hline 7 & & 270 & 340 \\
\hline 8 & & 90 & 340 \\
\hline 9 & & 90 & 340 \\
\hline 10 & & 70 & 340 \\
\hline 11 & & 90 & 340 \\
\hline 12 & & 80 & 340 \\
\hline 13 & & 90 & 330 \\
\hline 14 & & 100 & \\
\hline 15 & & 80 & \\
\hline 16 & & 80 & \\
\hline 17 & & 80 & \\
\hline 18 & & 80 & \\
\hline 19 & & 270 & \\
\hline 20 & & 105 & \\
\hline 21 & & 70 & \\
\hline 22 & & 70 & \\
\hline 23 & & 75 & \\
\hline 24 & & 85 & \\
\hline 25 & & 90 & \\
\hline 26 & & 95 & \\
\hline 27 & & 90 & \\
\hline 28 & & 80 & \\
\hline 29 & & 70 & \\
\hline 30 & & 80 & \\
\hline
\end{tabular}

Pakistan (cf. Rehman et al. 2011) and produced an early structure in the study area thus strengthening the Ham and Bell (2004) statement. The Kunar Fault in Afghanistan (represents the sidewise collision of the Eurasian and Indian plates) lies $\sim 80 \mathrm{~km}$ to the NW of the study area trending NNE-SSW and have an impact on the area thus resulting in the production of a macroscale fold having the same orientation as that of Kunar Fault (figure 20). In figure 20 the rose diagrams between $\mathrm{A}$ and $\mathrm{B}$ parts show the trends of FIA 1 and FIA 2. The upper rose diagram FIA 1 depicts the same orientation as Kunar Fault in figure 20(A) and macroscopic scale fold in figure 20(B). FIA 1, macro-scale fold axis and MKT show harmony in orientation in this part of the western hinterland zone. The fabric related with $\mathrm{D}_{2}, \mathrm{D}_{3}$ and $\mathrm{D}_{4}$ does not indicate any genetic relationship with the initial development of the main NNE-SSW trending fold. $\mathrm{S}_{2}$ foliation trending $\sim \mathrm{N}$ can also be tentatively correlated with the main macroscopic fold in the area because the trend of the main fold changes from NNE-SSW to $\mathrm{N}$ to the south of the study area (figure 20B). FIA 2 and $\mathrm{S}_{3}$ at the outcrop show similar $\mathrm{E}-\mathrm{W}$ orientation. This $\mathrm{D}_{3}$ deformation can be better correlated with that of MBT (almost $\mathrm{E}-\mathrm{W}$ trending). The $\mathrm{S}_{4}$ fabric trending NNW-SSE in the thin sections and at an outcrop scale shows resemblance in orientation to that of the Hazara-Kashmir syntaxis which has been rotated counterclockwise (see figure 20).

Various deformations are reported by numerous researchers in the northeastern part of the western hinterland zone. The present study area (the southwestern part of the hinterland zone) is correlated with the northeastern part of the western hinterland zone in terms of deformation. A regional map of the northeastern part of the western hinterland zone (cf. figure $1 \mathrm{~B}$ by Shah et al. 2011, 2012) exhibits two sets of main structures: (i) E-W trending south verging mega- to micro-scale folds and (ii) NNE-SSW and NNWSSE trending upright to overturned, west vergent, regional to meso-scale folds. The relative timing of these structures and their tectonic implication were argued by DiPietro and Lawrence (1991) and DiPietro et al. (2008) and it was interpreted that the NNE-SSW/NNW-SSE folds are older than the $\mathrm{E}-\mathrm{W}$ trending folds, vs. Coward et al. (1988), Treloar et al. (1989), Anczkiewicz et al. (1998), Llana-Funez et al. (2006) and Shah et al. $(2011,2012)$ who proposed an opposite relationship. The current structure analysis resolves this problem in favour of the first group of authors on the basis of FIA trends and meso-scale structures.

The $\mathrm{D}_{1^{-}}, \mathrm{D}_{2^{-}}$and $\mathrm{D}_{3^{-}}$-related structures in this part of the western hinterland zone show a remarkable resemblance to the F1/F2, F3 and F4 described by DiPietro and Lawrence (1991) and DiPietro et al. (2008) in the eastern part of the western hinterland zone. According to DiPietro et al. (2008) the northeastern part of the western hinterland has been affected by at least four events of deformation. The exposed parts of the western hinterland in Warsak, Nawagai, Malakand, Swat, Besham, Kaghan, Naran, Burawai, Rustam and Swabi have nicely preserved evidence of regional scale folds F1/F2, F3 and F4 that occurred during 

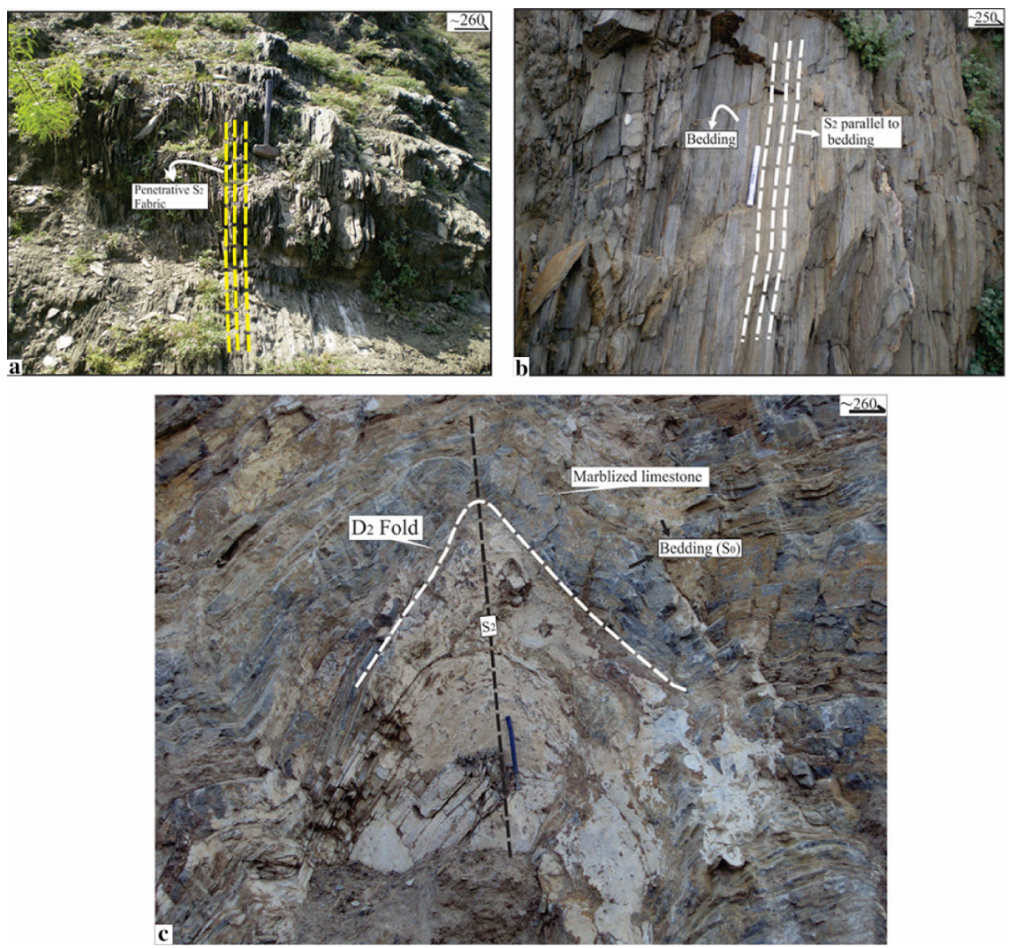

Figure 11. (A, B) Field photograph showing the $\mathrm{S}_{2}$ trend parallel to the bedding in the pelitic unit, (C) field photograph showing the $\mathrm{S}_{2}$ cleavage, which is perpendicular to the marbleised unit in the western part of the Lowara Mena Formation.
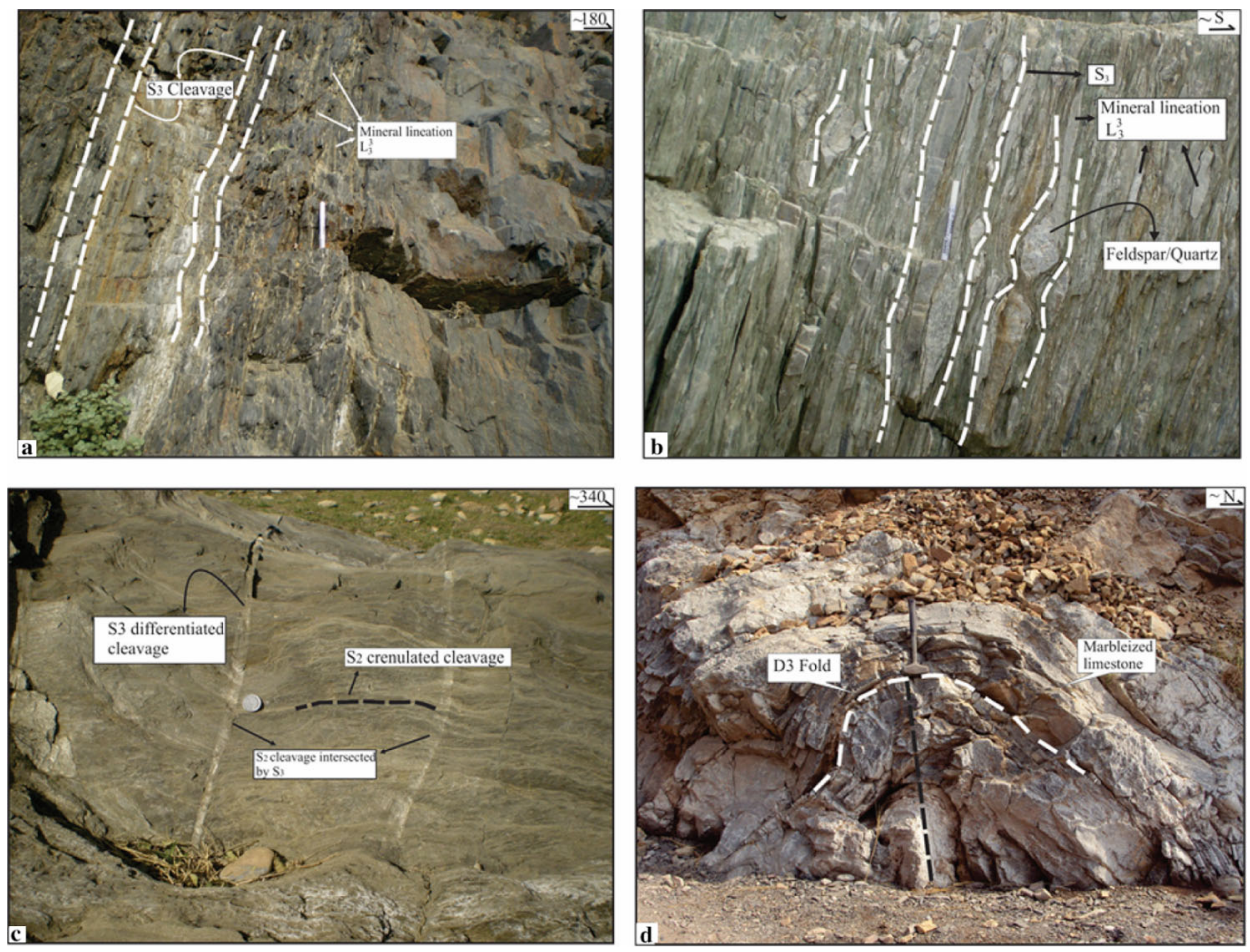

Figure 12. (A) Field photograph showing the steeply dipping $\mathrm{S}_{3}$ foliations and minerals lineation parallel to the $\mathrm{S}_{3}$, (B) field photograph showing $\mathrm{L}_{3}^{3}$ mineral lineation defined by aligned quartz/feldspar. $\mathrm{L}_{3}^{3}$ mineral lineation is trending parallel to the $\mathrm{S}_{3}$ foliation in the region, $(\mathbf{C})$ field photograph illustrating steeply dipping $\mathrm{S}_{3}$ and intersecting $\mathrm{S}_{2}$ in the area and (D) field photograph looking towards west showing the $\mathrm{F}_{3}$ sub-vertical fold in the marbleised limestone unit to the south of the study area. 

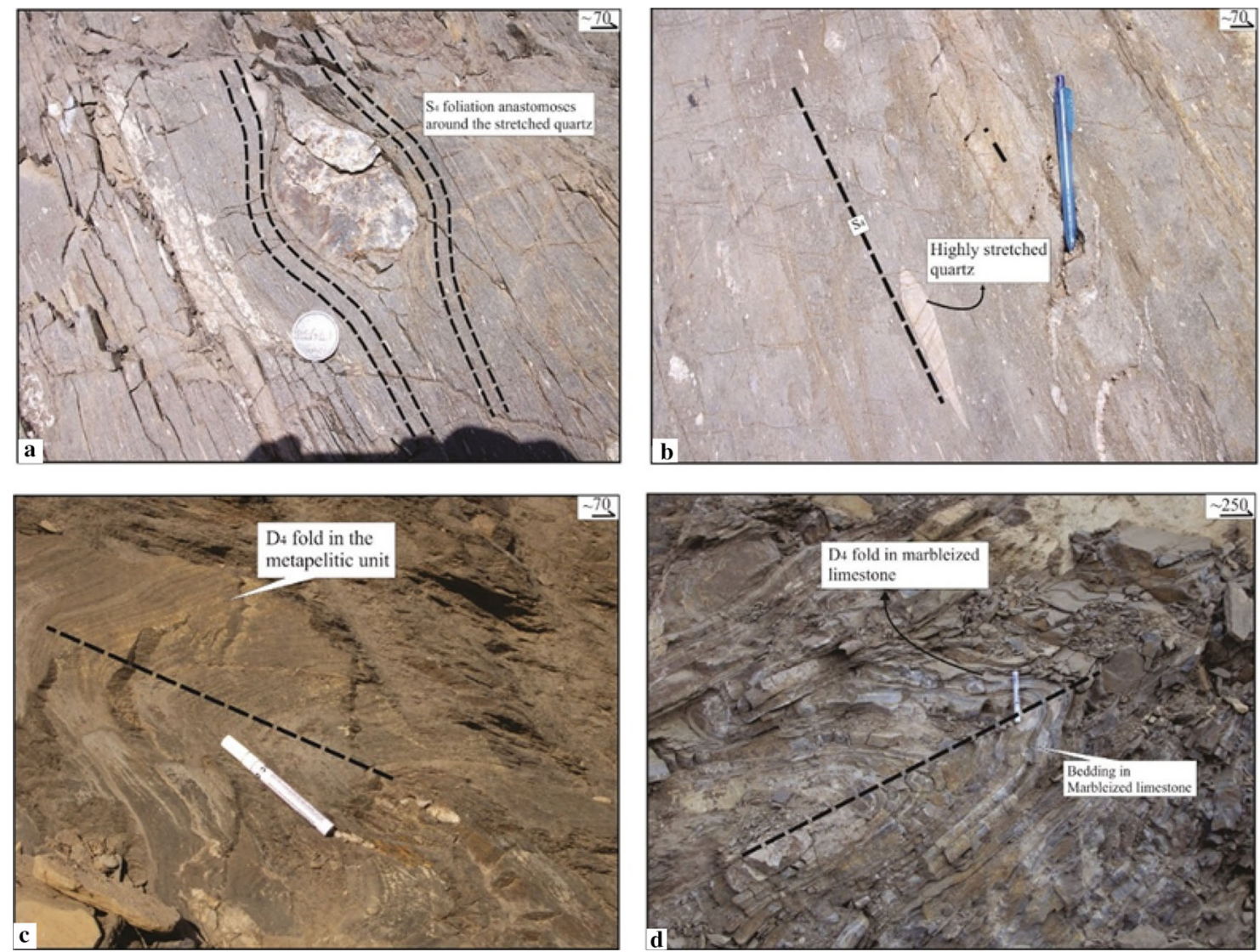

Figure 13. Field photographs (A, B) showing NW-SE trending and moderately dipping foliations $(\mathbf{C})$ field photograph showing $\mathrm{D}_{4}$-related mesoscopic folds. Length of the white marker is $13.2 \mathrm{~cm}$.

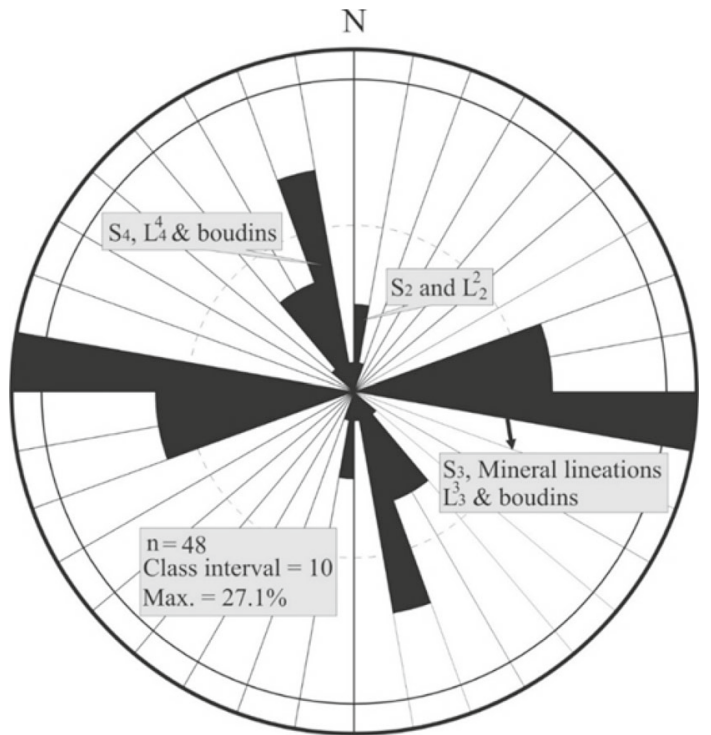

Figure 14. Equal area rose diagram showing the trends of mesoscopic structures preserved in the metapelitic schist of the Mula Gori area, northeastern Khyber Agency.

separate tectonic events (DiPietro and Lawrence 1991; DiPietro et al. 2008). The generally NESW trending pervasive $\mathrm{S}_{2}$ crenulation cleavage of

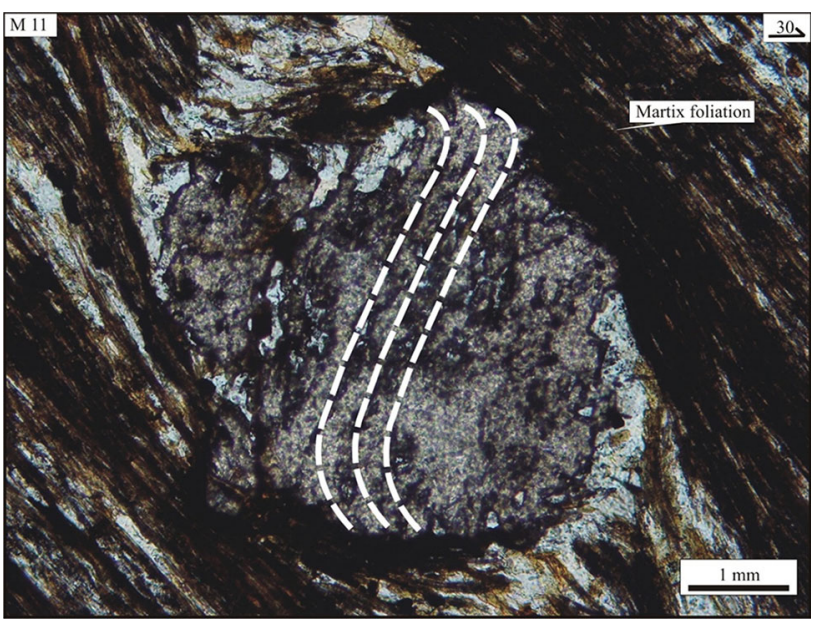

Figure 15. $\mathrm{S}_{1}$ is present only as inclusion trails in garnet porphyroblast.

$\sim 47 \pm 3$ Ma age is associated with the F1/F2 deformation event in the northeastern part of the western hinterland zone (see for details DiPietro et al. 2008). The map scale upright Eocene to the Early Oligocene F3 folds overprints both 

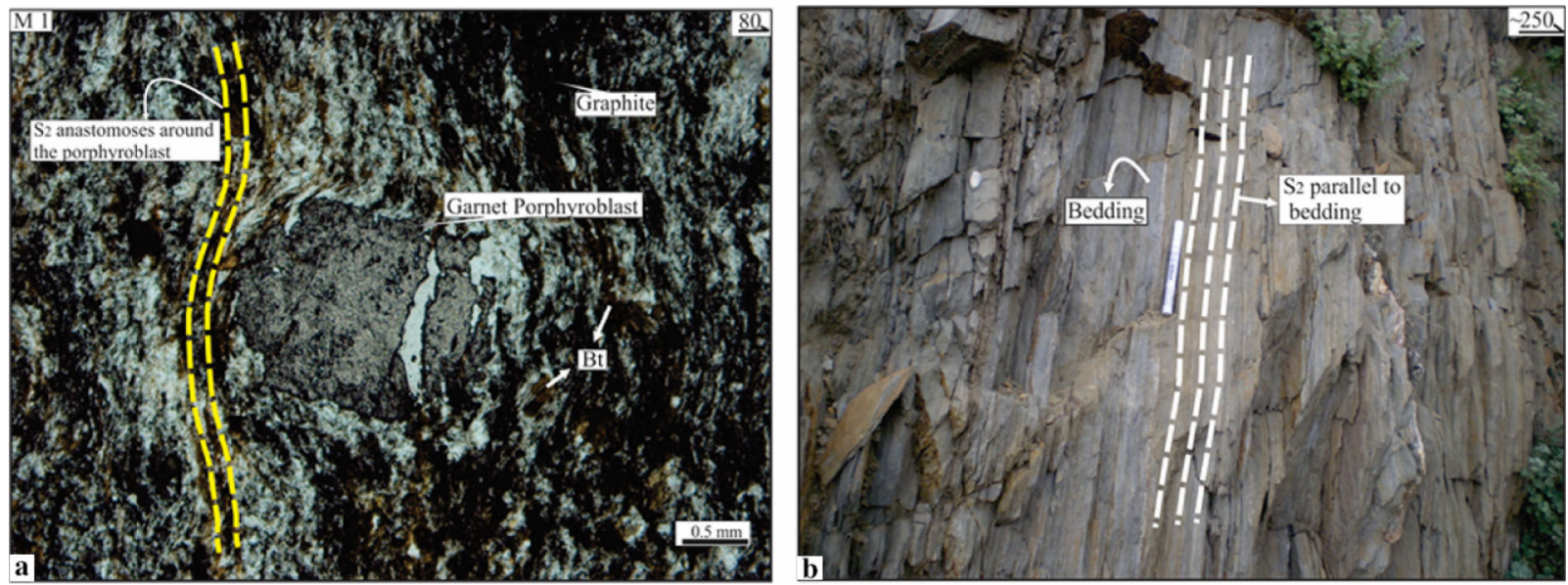

Figure 16. (A) Photomicrograph and (B) field photograph showing the resemblance of $\mathrm{S}_{2}$ in the vertical thin and at outcrop.
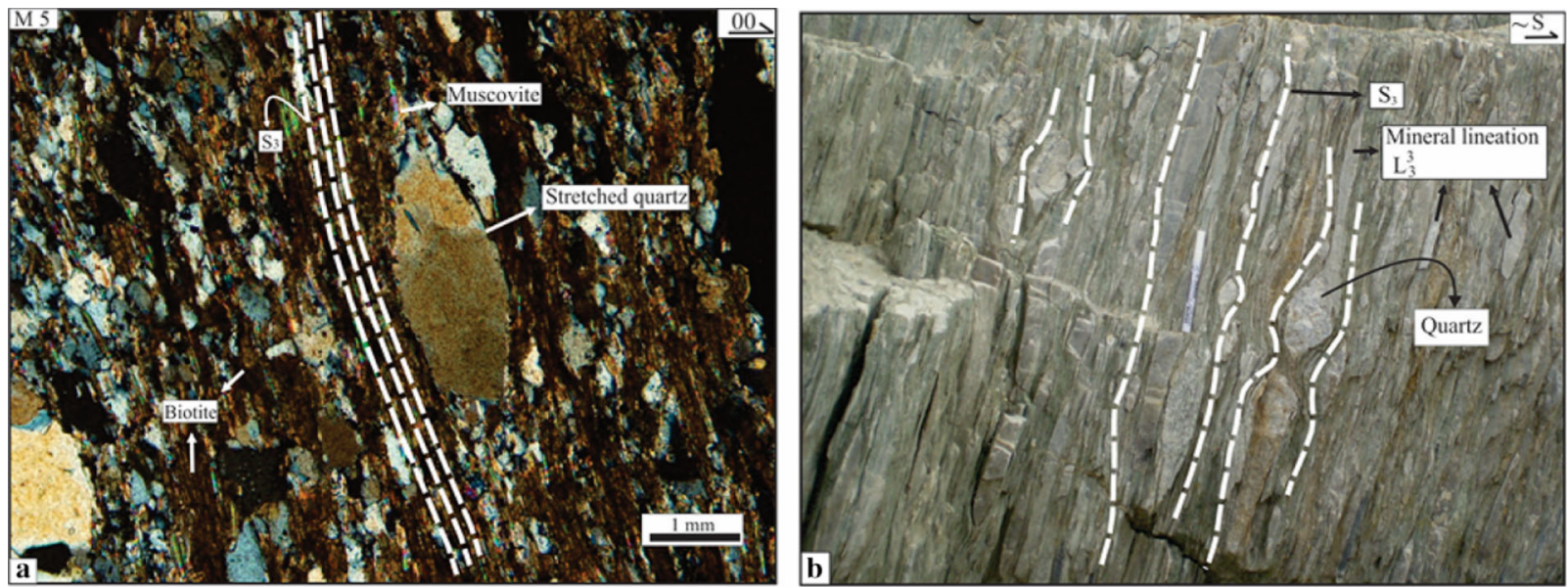

Figure 17. (A) Photomicrograph and (B) field photograph illustrating the similar trends of $\mathrm{S}_{3}$ in the studied vertical thin section and at outcrop.

the $\mathrm{F} 1 / \mathrm{F} 2$ folds and crenulates the pervasive $\mathrm{S}_{2}$ crenulation cleavage in the northeastern part of the western hinterland. The regional scale F3 folds trend NNE-SSW in the Nawagai region, Pinjkora Anticline (PA), Dargai, Kotah Dome (KD), Saidu, Loe Sar Dome (LD), Indus River Anticline (IA), Indus Syntaxis (IS) and Hazara before bending to the NE direction near the Kohistan fault in the north (cf. figure 1B of DiPietro et al. 2008). The map scale $\mathrm{E}-\mathrm{W}$ trending structures and lineations in the western hinterland developed during the F4 deformation event. The E-W trending fold axes related to F4 are nicely exposed in Pinjkora, Swat, Malakand, Rustam and Swabi (cf. figure 1B of DiPietro et al. 2008). The $\mathrm{E}-\mathrm{W}$ trending structures associated with F4 developed during the N-S horizontal bulk shortening at $\sim 31-23 \mathrm{Ma}$ and thus overprinted the NNE-SSW trending structures related with F3 across the northeastern part of the western hinterland zone (DiPietro et al. 2008). $\mathrm{D}_{1}$ (FIA 1) trending NNE-SSW of the present study resembles in orientation F3 of DiPietro et al. (2008) and FIA 3 of Shah et al. $(2011,2012) . \mathrm{D}_{2}$ resembles in orientation almost with F3 of DiPietro et al. (2008). $\mathrm{D}_{3}$ (FIA 2) trending ENE-WSW resembles in orientation with $\mathrm{F} 4$ of DiPietro et al. (2008) and with FIA 2 (E-W trending) of Shah et al. $(2011,2012) . \mathrm{D}_{4}$ resembles almost in orientation F1/F2 of DiPietro et al. (2008) while Shah et al. $(2011,2012)$ did not deduce this deformation event. It appears that $\mathrm{D}_{4} \mathrm{NNW}-\mathrm{SSE}$ fabrics that formed in the Mula Gori area resulted from the ENE-WSW bulk shortening related to the Hazara-Kashmir syntaxis tectonic event after the collision of the Kohistan island arc and the Indian plate. 

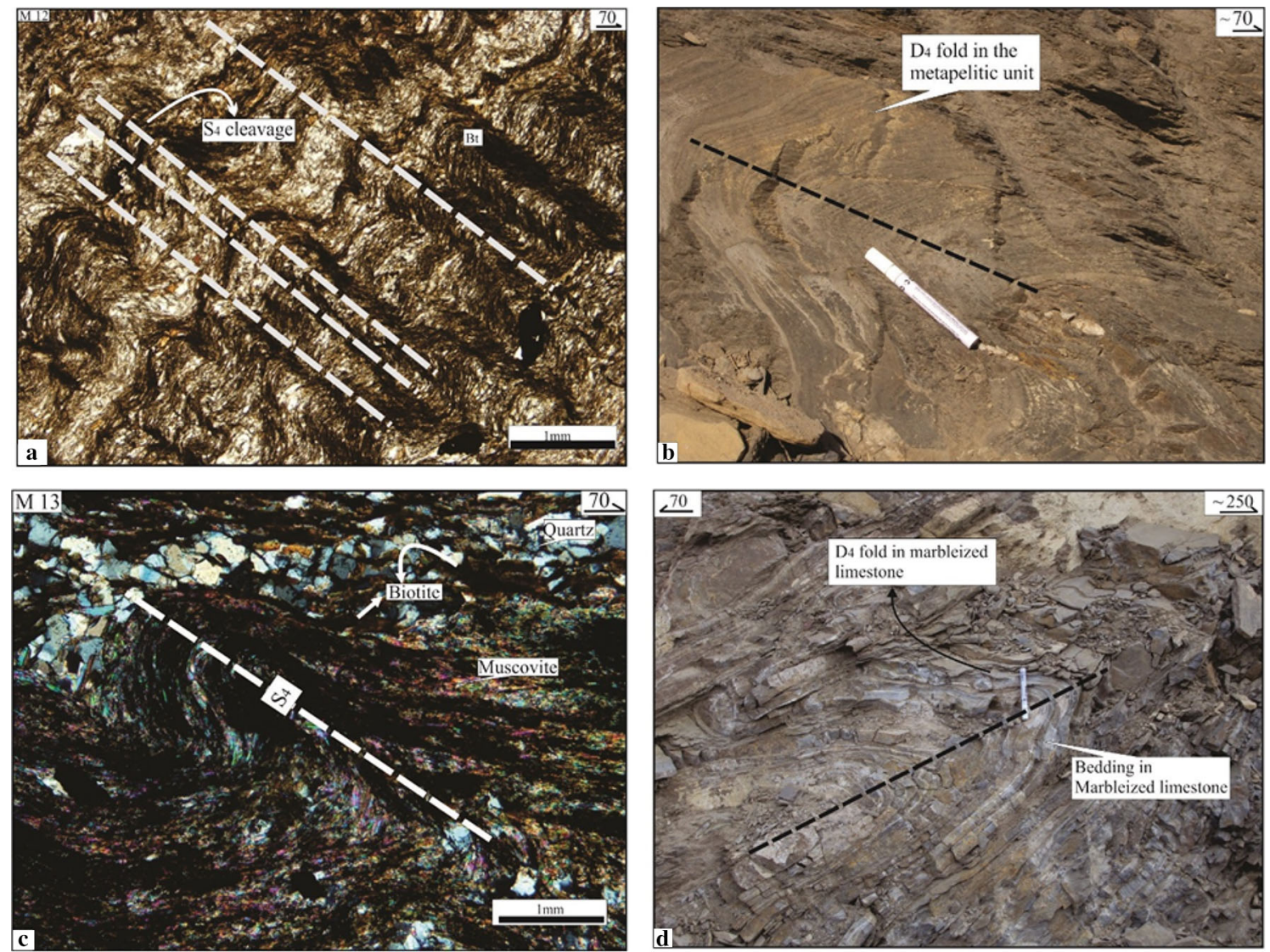

Figure 18. (A) Photomicrograph and (B) field photograph illustrating the same orientation of $\mathrm{S}_{4}$ in the studied vertical thin section and at outcrop. (C) Photomicrograph and (D) field photograph exhibiting the similar trends of $\mathrm{S}_{4}$ in the studied vertical thin section and at the outcrop level. In both the cases $\mathrm{S}_{4}$ is dipping towards the east.
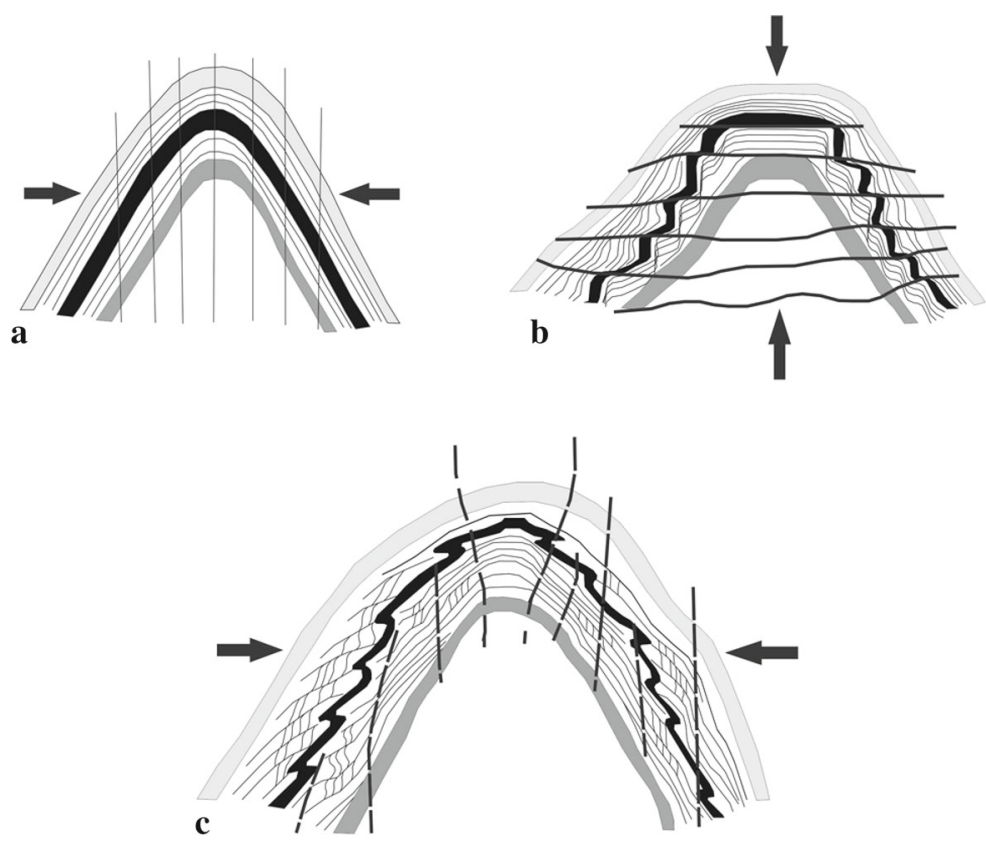

Figure 19. Series of sketches of cross-sections of a large regional fold showing tightening, reduction in size and modification in shape during the successive periods of subhorizontal and subvertical shortening. Note the main fold axis orientation remains same throughout the deformation events (after Ham and Bell 2004). 


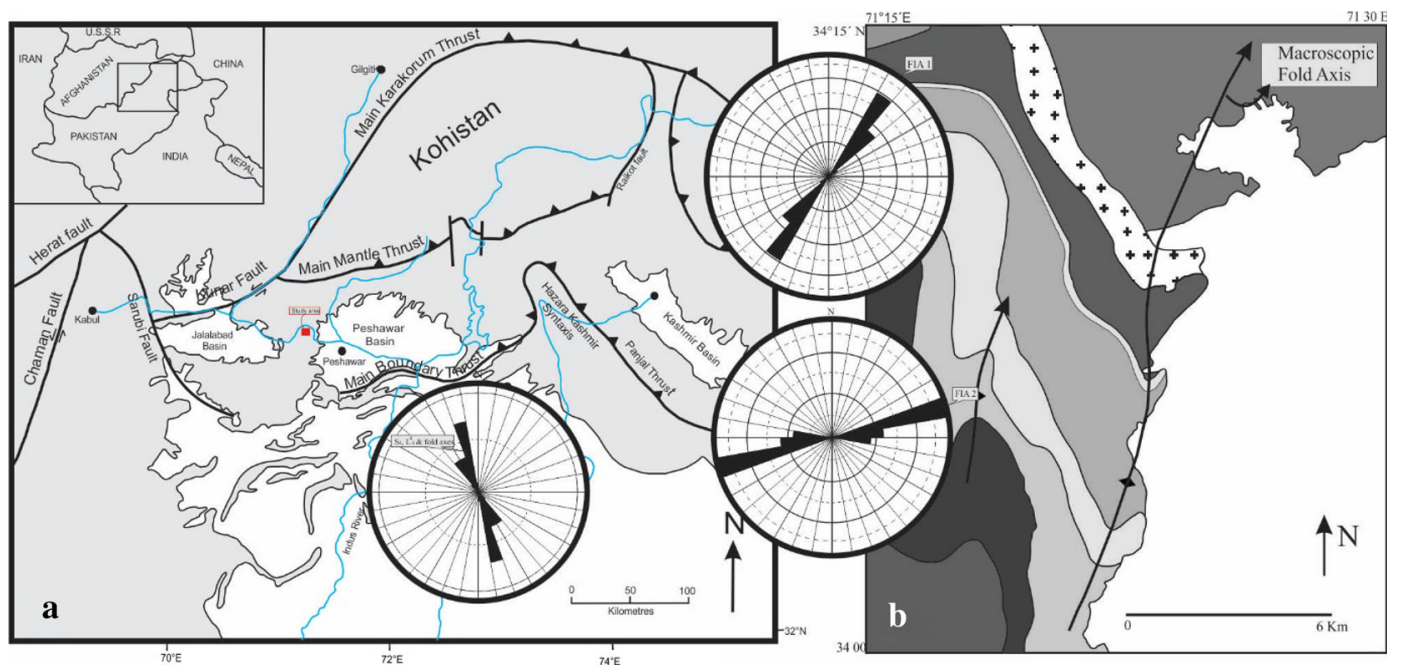

Figure 20. (A) Study area with a red box showing proximity to the Kunar Fault on the left trending (NNE-SSW) in the vicinity of Afghanistan (after Pogue et al. 1992) and (B) demarcating the geological map of the study area. The upper rose diagram shows the orientation of FIA 1 and the lower one is representing the orientation of FIA 2 while the rose diagram (to the left) in $\mathrm{A}$ shows trends of $\mathrm{S}_{4}$ foliations and $\mathrm{D}_{4}$ fold axes.

\section{Conclusions}

Micro, meso and macroscopic structures in the Mula Gori area not only show resemblance in orientation relative to each other in a sequential manner but also to the tectonic features of the region that resulted from the collision of the Indian and Eurasian plates. These structures seem to have developed at the same time in the bulk shortening trend in this southwestern part of the western hinterland zone. Microscopically $\mathrm{S}_{1}$ is only preserved as inclusion trails in the garnet porphyroblasts and is regarded as the product of $\mathrm{D}_{1}$ deformation events, showing remarkable resemblance with the macroscopic scale fold axis and Kunar Fault (extension of MKT), trending NNESSW in the region. In another words, the main macroscopic fold axis shows the earliest event of deformation in the area rather than being considered as the product of the latest deformation event. $\mathrm{F}_{2} / \mathrm{S}_{2}$ in field trending $\sim \mathrm{N}$ exhibits the same orientation to that of $\mathrm{S}_{2}$ in thin sections. $\mathrm{D}_{3}$ deformation events produced FIA 2 trending ENE-WSW in garnet porphyroblasts, $\mathrm{S}_{3}$ foliation and fold axes at the outcrop scale indicate NNE-SSW horizontal bulk shortening. $\mathrm{D}_{3}$ deformation is the most dominant event and shows resemblance in orientation to that of $\mathrm{MBT}$. $\mathrm{D}_{4}$ events produce NNW-SSE foliations/fold axes at micro and mesoscales resulting from the ENEWSW bulk shortening, similar to the HazaraKashmir syntaxis. $\mathrm{S}_{4}$ foliations and fold axes and mineral lineations are the imprint of the Hazara-Kashmir syntaxis in this part of the Lesser Himalayas.

\section{Acknowledgements}

The National Centre of Excellence in Geology (NCEG), University of Peshawar financed the studies. Oriented vertical thin sections were prepared at the rock cutting laboratory of NCEG. Constructive journal reviews were provided by Dr Sayandeep Banerjee and Dr Soumyajit Mukherjee. Their valuable suggestions/comments improved the quality of the paper. Many thanks to Prof Saibal Gupta for the editorial support.

\section{References}

Adshead-Bell N S and Bell T H 1999 The progressive development of a macroscopic upright fold pair during five near-orthogonal foliation-producing events: Complex microstructures versus a simple macroscopic; Tectonophys. 306 121-147.

Ahmad M, Ali K S S, Khan B, Shah M A and Ihsan U 1969 The geology of the Warsak Area, Peshawar, West Pakistan; Geol. Bull. Univ. Peshawar 4 44-78.

Ali A 2010 The tectono-metamorphic evolution of the Balcooma Metamorphic Group, north-eastern Australia: A multidisciplinary approach; J. Metamorph. Geol. $28397-$ 422.

Ali A, Yar M, Khan M A and Faisal S 2016 Interrelationships between deformation and metamorphic events across the Western Hinterland Zone, NW Pakistan; 
J. Earth Sci. 27(4) 584-598, https://doi.org/10.1007/ s12583016-0717-1.

Anczkiewicz R, Burg J P, Hussain S S, Dawood H, Ghazanfar M and Chaudhry M N 1998 Stratigraphy and structure of the Indus Suture in the Lower Swat, Pakistan, NW Himalaya; J. Asian Earth Sci. 16(2-3) 225-238.

Bell T H 1986 Foliation development and refraction in metamorphic rocks: Reactivation of earlier foliations and decrenulation due to shifting patterns of deformation partitioning; J. Metamorph. Geol. 4 421-444.

Bell T H and Hickey K A 1998 Multiple deformations with successive subvertical and subhorizontal axial planes in the Mount Isa Region: Their impact on geometric development and significance for mineralization and exploration; Econ. Geol. 93 1369-1389.

Bell T H and Welch P W 2002 Prolonged acadian orogenesis: Revelation from foliation intersection axis (FIA) controlled monazite dating of foliations in porphyroblasts and matrix; Am. J. Sci. 302 549-581.

Bell T H, Forde A and Wang J 1995 A new indicator of movement direction during orogenesis: Measurement technique and application to the Alps; Terra Nova 7 500-508.

Bell T H, Ham A P and Hickey K A 2003 Early formed regional antiforms and synforms that fold younger matrix schistosities: Their effect on site of mineral growth; Tectonophys. 367 253-278.

Bell T H, Ham A P and Kim H S 2004 Partitioning of deformation along an orogen and its effect on porphyroblast growth during orogenesis; J. Struct. Geol. 26 825-845.

Burbank D W 1983 Multiple episodes of catastrophic flooding in the Peshawar basin during the past 700,000 years; Geol. Bull. Univ. Peshawar 16 43-49.

Coward M P, Butler R W H, Chambers A F, Graham R H, Izatt C N, Khan M A, Knipe R J, Prior D J, Treloar P J and Williams M P 1988 Folding and imbrications of the Indian crust during Himalayan collision; Phil. Trans. Roy. Soc. London, Ser. A 326 89-116.

DiPietro J A and Lawrence R D 1991 Himalayan structure and metamorphism south of the Main Mantle Thrust, Lower Swat, Pakistan; J. Metamorph. Geol. 9 481-495.

DiPietro J A and Pogue K R 2004 Tectonostratigraphic subdivisions of the Himalaya: A view from the west; Tectonics $231-20$

DiPietro J A, Ahmad I and Hussain A 2008 Cenozoic Kinematic history of the Kohistan fault in the Pakistan Himalaya; Geol. Soc. Am. Bull. 120 1428-1440.

Gansser A 1964 The geology of the Himalayas; Wiley Interscience, New York.

Ham A P and Bell T H 2004 Recycling of foliations during folding; J. Struct. Geol. 26 1989-2009.

Hayward N 1990 Determination of early fold axis orientations within multiply deformed rocks using porphyroblasts; Tectonophys. 179 353-369.

Huston D L 1990 The stratigraphic and structural setting of the Balcooma volcanogenic massive sulphide lenses, northern Queensland; Aust. J. Earth Sci. 37 423-440.

Kazmi A H and Rana R A 1982 Tectonic map of Pakistan; Geological Survey of Pakistan, Quetta.

Khan A, Aslam M and Khan R N 1989 Revised stratigraphy of the Paleozoic rocks, Khyber Agency, NWFP, Pakistan; Geol. Surv. Pakistan, Inf. Release No. 431 1-11.
Llana-Funez S, Burg J P, Hussain S S, Dawood H and Chaudhry M N 2006 Structural evolution of the footwall of the Indus Suture in Malakand (N Pakistan) during the Himalayan collision; J. Asian Earth Sci. 27 691706 .

Mukherjee S 2013 Channel flow extrusion model to constrain dynamic viscosity and Prandtl number of the Higher Himalayan Shear Zone; Int. J. Earth Sci. 102 1811-1835.

Mukherjee S 2015 A review on out-of-sequence deformation in the Himalaya; In: Tectonics of the himalaya (eds) Mukherjee S, Carosi R, van der Beek P, Mukherjee B K and Robinson D, Geol. Soc. London, Spec. Publ. $41267-$ 109.

Mukherjee S 2017 Review on symmetric structures in ductile shear zones; Int. J. Earth Sci. 106 1453-1468.

Mukherjee S, Mukherjee B and Thiede R 2013 (Guest eds) Geosciences of the Himalaya-Karakoram-Tibet Orogen thematic volume's editorial; Int. J. Earth Sci. 102 17571758 .

Mukherjee S, Carosi R, van der Beek P A, Mukherjee B K and Robinson D M 2015 Tectonics of the Himalaya: An introduction (eds) Mukherjee S, Carosi R, van der Beek P, Mukherjee B K and Robinson D, Geol. Soc. London, Spec. Publ. 412 1-3.

Pogue K R, Wardlaw B R, Harris A G and Hussain A 1992 Paleozoic and Mesozoic stratigraphy of Peshawar Basin: Correlation and implications; Geol. Soc. Am. Bull. 104 915-927.

Pogue K R, Hylland M D, Yeats R S, Khattak W U and Hussain A 1999 Stratigraphic and structural framework of Himalayan foothills, northern Pakistan; Geol. Soc. Am. Spec. Paper 328 257-274.

Rehman H U, Seno T, Yamamoto H and Khan T 2011 Timing of collision of the Kohistan-Ladakh Arc with India and Asia: Debate; Island Arc 20 308-328.

Sanislav I V 2010 A long-lived metamorphic history in the contact aureole of the mooselookmeguntic pluton revealed by in situ dating of monazite grains preserved as inclusions in staurolite porphyroblasts; J. Metamorph. Geol. 29 1-23.

Sayab M 2005 Microstructural evidences for N-S shortening in the Mount Isa Inlier (NW Queensland, Australia): The preservation of early $\mathrm{W}-\mathrm{E}$ trending foliations in porphyroblast revealed by independent 3D measurement techniques; J. Struct. Geol. 27 1445-1468.

Sayab M 2008 Correlating multiple deformation events across the Mesoproterozoic NE Australia using foliation intersection axes (FIA) preserved within porphyroblasts; Gondwana Res. 13 331-351.

Shah S M I, Siddiqi R A and Talent J A 1980 Geology of the eastern Khyber agency, North West Frontier Province, Pakistan; Rec. Geol. Surv. Pakistan 44 130.

Shah S Z, Sayab M, Aerden D G A M and Khan M A 2011 Foliation intersection axes preserved in garnet porphyroblasts from the Swat area, NW Himalaya: A record of successive crustal shortening directions between the Indian plate and Kohistan-Ladakh Island Arc; Tectonophys. 509 14-32.

Shah S Z, Sayab M, Aerden D G A M and Iqbal Q 2012 Formation mechanism and tectonic significance of millipede 
microstructures in the NW Himalaya; J. Asian Earth Sci. $593-13$.

Sharib A S A A A and Bell T H 2011 Radical changes in bulk shortening directions during orogenesis: Significance for progressive development of regional folds and thrusts; Precamb. Res. 188 1-20.

Tahirkheli R A K 1979 Geology of the Kohistan and adjoining Eurasian Indo-Pakistan continents, Pakistan; Geol. Bull. Univ. Peshawar 11 1-30.

Corresponding editor: SAIBAL GUPTA
Treloar P J, Williams M P and Coward M P 1989 Metamorphism and crustal stacking in the North Indian Plate, North Pakistan; Tectonophys. 165(1-4) 167184.

Treloar P J, Coward M P, Chambers A F, Izzat C N and Jackson K C 1992 Thrust geometries, interferences and rotations in the North-West Himalaya; In: Thrust tectonics (ed.) McClay K R, Chapman and Hall, New York, pp. 325-342. 